\title{
Habitat use and home range of brown-nosed coati, Nasua nasua (Carnivora: Procyonidae) in the Brazilian Cerrado biome
}

\author{
Roberto Guilherme Trovati ${ }^{1}$, Bernardo Alves de Brito ${ }^{2}$ \& José Maurício Barbanti Duarte ${ }^{3}$ \\ 1. Laboratório de Ecologia Animal, "Escola Superior de Agricultura Luiz de Queiroz" - ESALQ/USP, Piracicaba, Brazil; \\ rgtrovati@yahoo.com.br \\ 2. Departamento de Criação de Unidades de Conservação/IBAMA, Brasília, Brazil; bernardo.brito@ibama.gov.br \\ 3. Faculdade de Ciências Agrárias Veterinárias, UNESP - Universidade Estadual Paulista, Departamento de Zootecnia, \\ Núcleo de Pesquisa e Conservação de Cervídeos, Jaboticabal, Brazil; barbanti@fcav.unesp.br
}

Received 30-VII-2009. Corrected 19-I-2010. $\quad$ Accepted 22-II-2010.

\begin{abstract}
The brown-nosed coati (Nasua nasua) is a carnivorous species found in all the Brazilian biomes, some of which are endangered areas. The aim of this work was to determine the habitat use and selection, home range and core area of N. nasua in the Cerrado biome, central region of Tocantins, Brazil. The study was carried out in an area of approximately 20000 ha from May 2000 to July 2002. A total of seven box traps were placed in the area for 13 months, three of 11 captured animals were followed and monitored by radio-tracking during 13 months. The monitoring was conducted once a day, three times a week using a car and walking through the study area (radio-tracking and visual contact). The results demonstrate that these three males used more frequently the gallery forest formation, followed by cerrado and wetlands. The use of gallery forest by these animals indicated an habitat selection (Proportion test, $\mathrm{z}=12.98, \mathrm{p}<0.01$ ). Besides, adult males used the gallery forest more frequently (Fisher's exact test, $\mathrm{p}<0.01$ ) and wetlands less frequently (Fisher's exact test, $\mathrm{p}<0.01$ ) than juvenile males, without significant differences between animal ages for cerrado percentage of habitat use. Besides, results also showed a gallery forest selection by adult (Proportion test $\mathrm{z}=13.62, \mathrm{p}<0.01$ ) and juvenile (Proportion test $\mathrm{z}=2.68, \mathrm{p}<0.01$ ) males, and a wetland selection by the juvenile male (Proportion test $\mathrm{z}=3.90, \mathrm{p}<0.01$ ). The home ranges varied from 2.20 to $7.55 \mathrm{~km}^{2}$ for the Minimum Convex Polygon 100\% (MCP 100\%) and from 4.38 to $13.32 \mathrm{~km}^{2}$ for the Harmonic Mean 95\% (HM 95\%). The smallest home range overlap occurred between the adult males ( $\mathrm{Nm} 1$ and $\mathrm{Nm} 3$ ), and the greatest between the juvenile $\mathrm{Njm} 2$ and the adult $\mathrm{Nm} 1$. The average of the core area (HM 75\%) for the three monitored animals represented $21.29 \%$ of the home range calculated with HM $95 \%$. No overlap between core areas was observed for adult males, but, it was an overlap between the core area of the juvenile male and its band with that of the two adult males. The present study provides new data on core area size and frequency habitat use by adult and juvenile males of $N$. nasua in the Brazilian Cerrado, that may support conservation efforts. Rev. Biol. Trop. 58 (3): 1069-1077. Epub 2010 September 01.
\end{abstract}

Key words: core area, habitat selection, Nasua nasua, overlap, radio-tracking, savanna, Brazil.

The Nasua genus is made up of two coati species, Nasua narica and Nasua nasua, which present allopatric geographic distributions. The white-nosed ( $N$. narica) is found from the Southern United States to Southern Central America; and the brown-nosed ( $N$. nasua), is found in the whole South American continent (Decker 1991). These two species present very similar social structures, where the male adults are solitary animals, and the females live in bands together with the offspring and juvenile males up to two years of age; though there is flexibility in this time-frame (Gompper 1996, Gompper \& Decker 1998).

Generally, the existing information for both biological and ecological aspects of this genus is related to N. narica. Kaufmann (1962) was one of the pioneers to carry out field 
studies and observed behavior, reproduction, diet, social structure, and spatial movement aspects of this species. From this point on, various studies, on $N$. narica, by other researchers have focused in one or more of these aspects, and for which the spatial movement have been monitored by radio-tracking as it made possible to localize and follow-up of the animals (Lanning 1976, Gompper \& Krinsley 1992, Estrada et al. 1993, Ratnayeke et al. 1994, Gompper 1996, 1997, Valenzuela \& Ceballos 2000, Hass 2002, Valenzuela \& Macdonald 2002).

In relation to the $N$. nasua, available information is principally on morphological characteristics (Decker 1991, Emmons \& Feer 1997, Eisenberg \& Redford 1999, Marinho-Filho et al. 1998, Nowak 1999), behavior (Di Blanco \& Hirsh 2006, Hirsh 2007, Romero \& Aureli 2007, 2008) feeding habits (Schaller 1983, Redford \& Stearman 1993, Gompper \& Decker 1998, Beisiegel 2001, Alves-Costa et al. 2004, Alves-Costa \& Eterovick 2007, Beisiegel 2007, Hirsh 2009) and habitat use (Schaller 1983, Yanosky \& Mercolli 1992, Brooks 1993, Emmons \& Feer 1997, Marinho-Filho et al. 1998, Beisiegel \& Mantovani 2006), with only two studies on home range (Nakano-Oliveira \& Monteiro-Filho 2002, Beisiegel \& Mantovani 2006). These studies on the spatial movement of $N$. nasua provide information for anthropized areas of the Atlantic forest. Which shows that information on home range, core area, overlap between animal's home range, habitat use and other movement data are rare or even nonexistent for $N$. nasua in other biomes.

The Cerrado biome can be considered an endangered biome of Brazilian territory, such as the Atlantic forest. As the strategies for species conservation became a reality more present in this ecosystem due to loss of its natural areas, after human occupation and fragmentation (Klink \& Machado 2005), the information about basic ecological aspects of $N$. nasua, as spatial movement and habitat use for this biome, can be considered essential to guarantee the efficacy of these efforts. For this reason, the aim of this study was to highlight basic ecological aspects of the N. nasua species, like the determination of its habitat use, habitat selection, home range and core area for the Cerrado biome, in the central region of Tocantins State, Brazil.

\section{MATERIALS AND METHODS}

Study area: The study area consisted of approximately 20000 ha located in the surroundings of the mouth of the Capivara river $\left(48^{\circ} 25^{\prime} 14^{\prime \prime} \mathrm{S} 10^{\circ} 10^{\prime} 88^{\prime \prime} \mathrm{W}\right)$, an affluent of the left bank of the Tocantins river, that belongs to the municipality of Porto Nacional, State of Tocantins, Brazil. The area is made up of gallery forest $(22.80 \%)$, cerrado (tropical and woodland savanna) (67.4\%) and wetlands (hygrophilous forest) (9.8\%). The weather data available for the city of Porto Nacional indicated an average annual temperature always above $25^{\circ} \mathrm{C}$. The absolute maximum temperatures exceed $41^{\circ} \mathrm{C}$, while in June and July the minimum temperatures drop below $10^{\circ} \mathrm{C}$. Average annual rainfall is $1600 \mathrm{~mm}$.

Capture: The capture of animals for the placement of radio collars was carried out using seven box traps made of a steel structure with a guillotine door (Crawshaw 1997), measuring $60 \times 50 \times 110 \mathrm{~cm}$ (width, height and length, including the space for the bait) with a 2 to $3 \mathrm{~cm}$ space between the bars. The disposition of the traps was carried out based on the presence of signs (track and feces) on the roads and trails through the gallery forest (4 traps) and the cerrado (3 traps) physiognomy. The trapping period took 13 months (May 2000 to June 2001). Fruit such as: banana, orange, watermelon and pineapple were used as bait. Trap inspections were carried out daily at daybreak.

Physical restrain and chemical immobilization: The physical restrain of the animals was carried out by a ketch-all pole. Two anaesthetic combinations were used for chemical immobilization: ketamine hydrochloride and xylazine hydrochloride (mean \pm standard error, $11.25 \pm 0.81,1.18 \pm 0.09 \mathrm{mg} / \mathrm{kg}$, respectively); 
and tiletamine-zolazepam $(10 \mathrm{mg} / \mathrm{kg})$ (Trovati et al. 2006).

Radio-tracking and home range: VHF radio-tracking was used to monitor the $N$. nasua, with frequency between 150 and $152 \mathrm{MHz}$ (Telemetry Electronics Consultants, EUA). The telemetry equipment used was Telonics, radio collars-Mod-105 (which represents less than $2 \%$ of animals body weight), receiver-TR-4 and "type H" antenna-RA-2AK. The locations of the animals were estimated by triangulation method (White \& Garrott 1990, Jacob \& Rudran 2003) or by visual contact (direct observation). The visual points were recorded using GPS (Global Positioning System). The monitoring was conducted once a day, three times a week using a car and walking through the study area. All the azimuths were corrected, for data processing, taking into consideration the magnetic declination in relation to the geographic north, subtracted $20^{\circ}$ for each direction, carried out with a 2000 and 2001 compass.

The set of data resulting from the triangulation and from the visual contact records were analyzed in the program Tracker 1.1 (Camponotus 1994) which determined habitat use, home range, core area and overlap. The location data recorded was used to determine the animal's habitat use. For home range determination, the Minimum Convex Polygon (MCP) (Morh 1947) and the Harmonic Mean (HM) (White \& Garrott 1990) methods were used. For the MCP method, $100 \%$ of the locations were used, as outliers were not found. In terms of the HM, an option was made to use $95 \%$ of the locations in the calculus of the home range, since this method tends to overestimate the home range (Lopes \& Mantovani 2005), and with $75 \%$, the greatest area of concentration of locations within the home range - denominated core area - was determined. The use of $75 \%$ of the locations to determine the core area occurred because of the equal size found when using $50 \%$ of the locations. Besides, the examination of $75 \%$ of localizations can represent the major utilization frequency of this area when compared with the $50 \%$ of localizations, which reinforce the idea of a core area inside the home range. The percentage of the core area and home range overlaps among males monitored were calculated as the geometric mean of the overlapping area on each core area and home range (HM 95\%), respectively (Minta 1992). For habitat use, home range, core area and overlap, the only locations considered were those taken at least 24 hours apart, in order to minimize serial spatial correlation (independent locations) (Swihart \& Slade 1985).

In order to evaluate differences between the habitats (gallery forest, cerrado and wetlands) used by N. nasua (three animals), a variance analysis was carried out (ANOVA-Tukey test). To investigate the differences of habitat use between adult males ( $\mathrm{Nm} 1$ and $\mathrm{Nm} 3$ ) and the juvenile (Njm2) the mean habitat use was calculated for the adult males and then compared to the juvenile's using a proportion test followed by Fisher's exact test. To evaluate if the differences, observed on habitat use by the three animals monitored and between adults and juvenile males, indicated a habitat selection (considering the total amount of each habitat available in the study area) a proportion test was used. These analyses were done using Minitab 15.0 (Minitab 2006) and values of $\mathrm{p}<0.05$ were considered significant.

This study was approved by Brazilian Institute of Environmental and Natural Resources (IBAMA - Instituto Brasileiro do Meio Ambiente e dos Recursos Naturais Renováveis) under license number 009/2000 (process number: 02029.00621/01).

\section{RESULTS}

Capture efforts and monitored animals: With a trapping effort of 2730 trap-days, 11 coatis were captured (ten male and one female); eight on the gallery forest and three on the cerrado physiognomy. It was not observed any injuries to animals caused by the capture method used and they all were in a good health status when captured. Nevertheless, only three male coatis were monitored by radio-tracking: 
two adults (Nm1 and $\mathrm{Nm} 3$ ) and a juvenile (Njm2). The animal that was considered young belonged to a band, a fact that was observed during the capture and sighting of the animal. The capture of $\mathrm{Nm} 1$ and $\mathrm{Njm} 2$ took place within a four-day interval. However, the capture of $\mathrm{Nm} 3$ took place three months before the end of the monitoring period. It is important to point out that the alterations in the radio collar frequency of the juvenile (Njm2), due to a malfunction of the radiotelemetry equipment, lessened the number of locations when compared to those of the Nm1.

Habitat use: Significant differences were observed between the habits used (Tukey test, $\mathrm{p}=0.02$ ) (Fig. 1). All three monitored animals used the gallery forest habitat more frequently (mean \pm standard error, $62.20 \pm 12.00$ ), followed by the cerrado (24.10 \pm 5.31$)$ and the wetlands (13.67 \pm 6.97$)$. Considering the amount of each habitat available on the study area, the most frequent use of gallery forest indicated a habitat selection (Proportion test, $\mathrm{z}=12.98, \mathrm{p}<0.01$ ) by these three animals. Besides, differences were observed in terms of the percentage of habitat use mainly between solitary adult males (Nm1 and $\mathrm{Nm} 3$ ) and juvenile (Njm2) that belonged to a band. The adult males used the gallery forest more frequently (Fisher's exact test $\mathrm{p}<0.01$ )

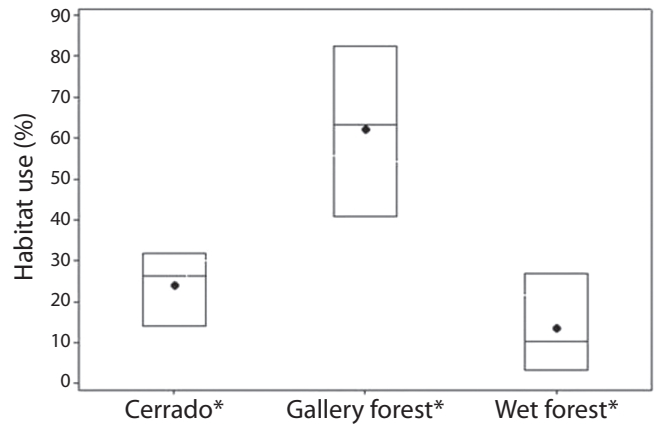

Fig. 1. Habitat selection for three of brown-nosed coati Nasua nasua (one juvenile and two adults) monitored in the Brazilian Cerrado.

and wetlands less frequently (Fisher's exact test, $\mathrm{p}<0.01$ ) than juvenile male; no significant differences between animals ages for the cerrado percentage of habitat use (Table 1). Thus, when evaluating habitat selection considering adult males and juvenile male, the results of the proportion test $(\mathrm{z}=3.90, \mathrm{p}<0.01)$ shows that the juvenile male makes habitat selection for wetland, but also for the gallery forest $(\mathrm{z}=2.68$, $\mathrm{p}<0.01)$ as the adult males $(\mathrm{z}=13.62, \mathrm{p}<0.01)$.

Home range: Coatis showed differences in home range size. The juvenile male ( $\mathrm{Njm} 2)$ had the greatest home range, followed by the adult males $\mathrm{Nm} 1$ and $\mathrm{Nm} 3$, respectively

TABLE 1

Habitat use (HU), home range (HR) and core area (CA) of three brown-nosed coati (Nasua nasua) in the Cerrado biome, Brazil

\begin{tabular}{|c|c|c|c|c|c|c|c|c|}
\hline \multirow{2}{*}{ Animals } & \multirow{2}{*}{$\mathrm{NL}^{\mathrm{a}}$} & \multirow{2}{*}{$\mathrm{MP}^{\mathrm{b}}$} & \multicolumn{3}{|c|}{ HU (\%) } & \multicolumn{2}{|c|}{$\mathrm{HR}\left(\mathrm{km}^{2}\right)$} & \multirow{2}{*}{$\begin{array}{l}\mathrm{CA}\left(\mathrm{km}^{2}\right) \\
\mathrm{HM} 75 \%\end{array}$} \\
\hline & & & Cerrado* & Gallery forest ${ }^{*}$ & Wetlands * & $\mathrm{MCP}^{\mathrm{c}} 100 \%$ & $\mathrm{HM}^{\mathrm{c}} 95 \%$ & \\
\hline Male (Nm1) & 85 & 13 & 14.00 & $82.50^{\dagger}$ & 3.50 & 3.80 & 4.38 & 1.02 \\
\hline Male (Njm2) & 44 & 7 & 32.00 & $41.00^{\dagger \infty}$ & $27.00^{\infty}$ & 7.55 & 13.32 & 2.82 \\
\hline Male $(\mathrm{Nm} 3)^{1}$ & 19 & 3 & 26.30 & $63.20^{\dagger}$ & 10.50 & 2.20 & 3.97 & $\begin{array}{l}0.40 \\
0.37\end{array}$ \\
\hline
\end{tabular}

a Number of locations for each animal;

b Monitoring period, expressed in months;

c MCP-Minimum Convex Polygon and HM-Harmonic Mean;

* Significant differences between habitats used (Tukey test, $\mathrm{p}<0.05$ );

$\dagger$ Selection habitat of gallery forest by the three animals (Proportion test, $\mathrm{p}<0.01$ );

$\infty$ Significant differences for the use of gallery forest and wetland between juvenile male and adult males (Fisher's exact test, $\mathrm{p}<0.01)$;

1 Animal registered two core areas for the calculus of HM $75 \%$. 
(Table 1). However, Nm1 was the one that had the greatest number of locations and the longest monitoring period among the animals (Table 1). The information allowed determining this animals' home range through cumulative curve analysis, while the other individuals did not reach the asymptote for such analysis (Fig. 2). Overlap was observed in the home range among all the animals and these had a large variation. The smallest overlap occurred between the adult males (Nm1 and Nm3) and the greatest between the juvenile $\mathrm{Njm} 2$ and the adult Nm1 (Table 2). Besides, during the month of September 2000 the adult male Nm1 was observed accompanying the band of the juvenile Njm2. Out of the eight observations made for this month, they were together $50 \%$ of the time.

Core area: The adult male $\mathrm{Nm} 3$ showed two core areas for the HM 75\%. The size observed for the core area (HM 75\%) of Nm1, $\mathrm{Njm} 2$ and $\mathrm{Nm} 3$ was $23.28 \%, 21.20 \%$ and $19.39 \%$ (one core was $10.07 \%$ of home range and the other $9.32 \%$ ) of the home range (HM $95 \%$ ), respectively (Table 1 ). The average size of the core areas was $21.29 \%$ of the home range (HM 95\%). No overlap between core areas was observed for the two $\mathrm{Nm} 1$ and $\mathrm{Nm} 3$ adult males. However, there was overlap between the core area of the juvenile male (Njm2) and its band with the core area of the two adult males (Table 2).

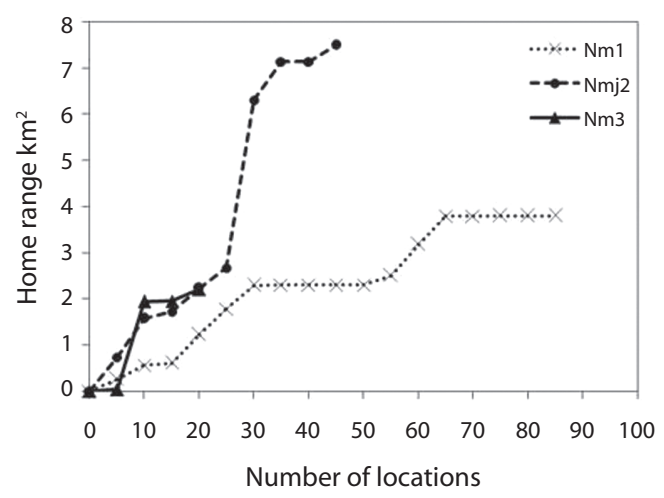

Fig. 2. Cumulative curve of the home range of brownnosed coati Nasua nasua calculated with MCP during the monitoring period of the animals (Nm1-13 months, Njm2-7 months and Nm3-3 months).

\section{DISCUSSION}

Habitat use: Gompper \& Decker (1998) report that $N$. nasua mainly occupy wooded habitats. In the Cerrado biome (tropical savanna), the greater part of wooded habitats is represented by the gallery forest vegetation type, and the results of this work confirm this fact. Marinho-Filho et al. (1998) had already observed that in the Cerrado biome coatis occupy the gallery forests, using sporadically open areas. However, it had been described that the $N$. nasua can use multiple environmental layers (Schaller 1983, Brooks 1993, Emmons \& Feer

TABLE 2

Home range overlap and core area overlap of three of brown-nosed coati (Nasua nasua) in the Cerrado biome, Brazil

$\begin{array}{lccc}\text { Animals } & \begin{array}{c}\text { Home range overlap } \\ \text { MCP } 100 \%\end{array} & \begin{array}{c}\text { Home range overlap } \\ \text { HM }^{\mathrm{a}} 95 \%\end{array} & \begin{array}{c}\text { Core area overlap } \\ \text { HM } 75 \%\end{array} \\ (\mathrm{Nm} 1) \times(\mathrm{Njm} 2) & 41.40 & 32.90 & 36.20 \\ (\mathrm{Nm} 1) \times(\mathrm{Nm} 3) & 9.10 & 10.00 & - \\ (\mathrm{Njm} 2) \times(\mathrm{Nm} 1) & 82.40 & 100.00 & 100.00 \\ (\mathrm{Njm} 2) \times(\mathrm{Nm} 3)^{1} & 27.70 & 53.70 & 21.60 \\ (\mathrm{Nm} 3) \times(\mathrm{Nm} 1) & 5.30 & 9.10 & - \\ (\mathrm{Nm} 3) \times(\mathrm{Njm} 2)^{1} & 8.10 & 16.00 & 2.80\end{array}$

a MCP-Minimum Convex Polygon and HM-Harmonic Mean.

1 Core area overlap between of the $\mathrm{Nm} 3$ and the Njm 2 occurred with the lowest core area that this animal present for HM $75 \%$ (Table1). 
1997, Beisiegel \& Mantovani 2006, AlvesCosta \& Eterovick 2007). In the present study it was also observed the use of different habitat physiognomies of the Cerrado biome (gallery forest, followed by cerrado and wetlands) by the monitored animals probably because of plastic behavior of this species and differences of resources availability among habitats. However, a habitat selection was observed for the gallery forest by the three animals monitored; which can be occurred due to greater resources availability of this area when compared to the other habitats of the studied area.

The N. nasua also seems to exploit the multiple habitat of different ways depending on animal age (solitary adult males and juvenile males associated to a band), as described for N. narica (Venezuela \& Ceballos 2000). The more frequent use of the gallery forest by adult males when compared to juvenile male and its band, could be related to their greater energetic requirement, which could be better fulfilled in a richer resource habitat, as the gallery forest (Ribeiro \& Marinho-Filho 2005). More over, solitary adult males can prefer to spend more time in a more protective habitat, as gallery forest, than the juvenile male that lives in a band, as described for other mammals species that live in social structures similar to coatis (Apollonio et al. 1998). This explanation could be reinforced by the more frequent use of wetland, a habitat less protective than gallery forest considering the covered vegetation area, by the juvenile male and its band; which in this study represented also a habitat selection by animals of this age. However, further studies on habitat selection based on resources availability and behavior with greater number of animals must be conducted to support evidence for this interpretation.

Home range: The results found for the home range of the $N$. nasua, calculated with both the MCP and the HM 95\% (Table 1) were higher than those observed for N. narica monitored by Kaufmann (1962) \& Gompper (1997) on tropical rainforest of Panamá. The smallest sized home range recorded by the referred authors could be associated with the differences that exist between the study areas. The tropical rainforest has a greater abundance of resources such as food and water when compared with the Cerrado biome, and according to Valenzuela \& Macdonald (2002) the distribution of these resources can affect the home range size. However, in the other study, conducted with $N$. nasua in a transition area of Cerrado and Atlantic forest, Nakano-Oliveira \& MonteroFilho (2002) founded home ranges sizes for a solitary male individual $22.40 \%$ larger than the one found for the solitary male, which reached the asymptote, in this study (Cerrado biome). Besides, when the home range sizes of both solitary males of the present study (2.20 and $3.80 \mathrm{~km}^{2}$ ) were compared to home ranges found by other authors for solitary males of $N$. narica (Venezuela \& Ceballos $2000\left(2.17-5.94 \mathrm{~km}^{2}\right)$, Hass $2002\left(2.79-9.60 \mathrm{~km}^{2}\right)$, some similarities between them were observed, even though the mentioned studies were conducted in different habitats than Cerrado (dry tropical forest and heterogeneous mountain habitat, respectively). These variations on home range sizes among studies could reflect, not only the resources availability of these different habitats, but also differences in predator densities, and sample size found between the study areas.

The home range of the juvenile male Njm2 (and its band), calculated for both MCP and HM 95\%, presented approximately twice to three times the size of the areas calculated for the adult males $\mathrm{Nm} 1$ and $\mathrm{Nm} 3$, even though his asymptote was not reached. It was previously described for $N$. narica (Hass 2000) and N. nasua (Nakano-Oliveira \& Monteiro-Filho 2002, Beisiegel \& Mantovani 2006) that the home range of animals belonged to the bands are larger than solitary animals. Since the coatis are the only carnivore species having group-living juvenile males associated to adult females and solitary adult males (Kaufmann 1962, Gompper 1996), the larger home range observed for juvenile males associated to a band, could be related to a higher energetic need due to lower activity pattern of coatis bands when compared to adult solitary males, 
as described for $N$. narica (Valenzuela \& Ceballos 2000).

The home range overlap between solitary males and the bands in the Nasua genus could be considered a reproductive strategy, as the males increased their reproductive success if they learn where the females are most liked to be located (Hass 2002). Similarly, the overlap amount between home ranges can be determined by the benefits of remaining in a familiar area, compete for resources with other individuals, and the cost of using unfamiliar or less productive areas (Valenzuela \& Ceballos 2000). Thus, the low average of home range overlap $(7.2 \% \mathrm{MCP})$ observed between the solitary males (Nm1 and $\mathrm{Nm} 3$ ) of $N$. nasua, when compared with the average (44\%) for the N. narica (Valenzuela \& Ceballos 2000), could be related to the existence of social structure plasticity, already observed by Gompper \& Krinsley (1992). Besides, sometimes during September, the adult male Nm1 accompanied the band to which the juvenile male $\mathrm{Njm} 2$ belonged, and this behavior was associated with possible reproductive aspects. According to Beisiegel (2001), N. nasua males generally associate themselves with bands during mating periods, which occurs in August for the Southeast. However, it was recently described in the Tiete Ecological Park (Brazil) (Resende et al. 2004) and Iguazu National Park (Argentina) (Di Blanco \& Hirsh 2006), that $N$. nasua adult males stay with bands during all months of year, which reinforces the existence of plasticity by this species.

Core area: The average size of core areas in relation to home range observed for the $N$. nasua was identical to that found for $N$. narica in the Southeast area of Arizona-USA (Hass 2002), even though methods used to accesses core areas were different. Although, Kaufmann (1962) found average size of the core areas in relation to home range of $40 \%$ for $N$. narica in Barro Colorado Island, Panamá, which is almost two times the average size of $21.3 \%$ observed in the present study. This is possibly related to the previously mentioned factors that determine the size difference on home range among various studies, as the resource availability in these areas. Few authors are concerned with estimating and understanding what the core area is within the home range of mammals (Kaufmann 1962, Hass 2002). However, this concept could be important for a better comprehension of possible territories, refuges and/or availability of resources (Kaufmann 1962). The core area observed for both adult males $\mathrm{Nm} 1$ and $\mathrm{Nm} 3$ were not overlapped, whereas both core areas from adult males overlapped the core area of juvenile male Njm2 and its band. This suggests that these core areas were probably defended as a territory by the adult males while they use part of the core area of band associated to the juvenile male. Nevertheless, the absent of overlap between adult males core areas can be also attributed to the few number of animals monitored in this study.

Finally, this study corroborates an early description which stated that home range size of solitary adult males of $N$. nasua is smaller than the animals associated to the bands. Besides, it provides new information about core size for this species and use frequency, by adult and juvenile males, of different habitats available on an endangered biome (Cerrado), even though further studies with possible higher number of monitored animals must be conducted to confirm these patterns.

\section{ACKNOWLEDGMENTS}

The authors would like to thank the Projeto Fauna (Investico/Ulbra-TO) for the funding of this project and to all those, who in some way, collaborated. Mainly, the field and office technicians: Ricardo, Janair, Divino, Zé, Franco, Kelto, Avanir and Leandra Lofego, Pedro Heber Ribeiro for their belief in this research. We would also like to thank all the friends of Núcleo de Pesquisa e Conservação de Cervídeos-UNESP/Jaboticabal. We thank Marina Salles Munerato for their essential collaboration. 


\section{RESUMEN}

El coatí Nasua nasua es una especie de prociónido que se distribuye en todos los biomas brasileños, algunos de los cuales son zonas amenazadas. Sin embargo, hay pocos estudios sobre el uso de hábitat, área de acción y centro de esta especie. En el bioma Cerrado de la región central de Tocantins, Brasil se determinó el uso y selección de hábitat, área de acción y centro de $N$. nasua. El estudio se llevó a cabo en un área de aproximadamente 20000 has de mayo 2000 a Julio 2002. Durante 13 meses se colocaron en la zona siete trampas, tres de 11 animales capturados fueron seguidos y controlados por radio-seguimiento por un periodo de 13 meses. El monitoreo se llevó a cabo una vez al día, tres veces por semana, caminando por el área de estudio o en carro (radio-seguimiento y contacto visual). Los resultados del estudio demostraron que los tres individuos ocuparon más frecuentemente las formaciones de bosque de galería, seguido por cerrado y bosque húmedo. Las áreas de acción variaron entre 2.20 y $7.55 \mathrm{~km}^{2}$ para el polígono mínimo convexo (PMC), y de 4.38 a 13.32 para la media harmónica $\mathrm{MH}$ 95\%. El área centro (MH 75\%) fue equivalente a $21.29 \%$ del área de acción calculada para la media harmónica MH 95\%. Este estudio provee información útil para los esfuerzos de conservación de la especie en el Cerrado brasileño, ya que proporciona nueva información sobre el tamaño del área centro y la frecuencia de uso de hábitat de dos machos adultos y un jóven de $N$. nasua.

Palabras clave: área centro, Nasua nasua, radio-telemetría, sabana, selección de hábitat, solapamiento, traslape.

\section{REFERENCES}

Alves-Costa, C.P \& P.C Eterovick. 2007. Seed dispersal services by coatis (Nasua nasua, Procyonidae) and their redundancy with other frugivores in Southeastern Brazil. Acta Oecol. 32: 77-92.

Alves-costa, C.P., G.A.B. Fonseca \& C. Christofaro. 2004. Variation in the diet of the brown-nosed coati (Nasua nasua) in Southeastern Brazil. J. Mammal. 85: 478482.

Apollonio, M., S. Focardi, S.Toso \& L. Naci. 1998. Habitat selection and group formation pattern of follow deer Dama dama in a submediterranean environment. Ecography 21: 225-234.

Beisiegel, B.M. 2001. Notes on the coati, Nasua nasua (Carnivora: Procyonidae) in an Atlantic forest area. Braz. J. Biol. 61: 689-692.

Beisiegel, B.M. 2007. Foraging Association between coatis (Nasua nasua) and Birds of the Atlantic Forest, Brazil. Biotropica 39: 283-285.
Beisiegel, B.M. \& V. Mantovani. 2006. Habitat use, home range and foraging preferences of the coati Nasua nasua in a pluvial tropical Atlantic forest area. J. Zool. (Lond.) 269: 77-87.

Brooks, D.M. 1993. Observations on procyonids in Paraguay and adjacent regions. Small Carniv. Conserv. 8: 3-4.

Camponotus, A.B. 1994. Tracker version 1.1 Wildlife tracking and analysis software. User manual Sweden, Camponotus, A.B.

Crawshaw Jr. P.G. 1997. Recomendações para um Modelo de Pesquisa sobre Felídeos Neotropicais, p. 70-94. In C. Valladares-Padua, R.E. Bodmer \& L. Cullen Jr. (eds.). Manejo e Conservação de Vida Silvestre no Brasil. CNPq, Sociedade Civil de Mamirauá, Manaus, Amazonas, Brasil.

Decker, D.M. 1991. Systematics of the coatis, Genus Nasua (Mammalia: Procyonidae). Proc. Biol. Soc. Wash. 104: 370-386.

Di Blanco, Y. \& B.T. Hirsh. 2006. Determinants of vigilance behavior in the ring-tailed coati (Nasua nasua): the importance of within-group spatial position. Behav. Ecol. Sociobiol. 61: 173-182.

Emmons, L.H. \& F. Feer. 1997. Neotropical rain forest mammals: a field guide. University of Chicago, Chicago, USA.

Eisenberg, J.F. \& K.H. Redford. 1999. Mammals of the neotropics: the central neotropics. University of Chicago, Chicago, USA.

Estrada, A., G. Halffter, R. Coates-Estrada \& A.D.A. Merritt Jr. 1993 Dung beetles attracted to mammalian herbivore (Aloutta palliata) and omnivore (Nasua narica) dung in the tropical rain forest of Los Tuxtlas, Mexico. J. Trop. Ecol. 9: 45-54.

Gompper, M.E. \& J.S. Krinsley. 1992. Variation in social behavior of adult male coatis (Nasua narica) in Panama. Biotropica 24: 216-219.

Gompper, M.E. 1996. Sociality and asociality in whitenosed coatis (Nasua narica): foraging costs and benefits. Behav. Ecol. 7: 254-263.

Gompper, M.E. 1997. Population ecology of the whitenosed coati (Nasua narica) on Barro Colorado Island, Panama. J. Zool. (Lond.) 24: 441-455.

Gompper, M.E. \& D.M. Decker 1998. Nasua nasua. Mamm. Species 580: 1-9. 
Hass, C.C. 2002. Home-range dynamics of white-nosed coatis in Southeastern Arizona. J. Mammal. 83: 934-946.

Hirsh, B.T. 2007. Spoiled Brats: Is Extreme Juvenile Agonism in Ring-Tailed Coatis (Nasua nasua) Dominance or Tolerated Aggression? Ethol. 113: 446-456.

Hirsh, B.T. 2009. Seasonal variation in the diet of ringtailed coatis (Nasua nasua) in Iguazu, Argentina. J. Mammal. 90: 136-143.

Jacob, A.A. \& R. Rudran. 2003. Radiotelemetria em estudos populacionais, p. 285-342. In L. Cullen Jr., R. Rudran \& C. Valadares-Padua (eds.). Métodos de estudos em biologia da conservação e manejo da vida Silvestre. Universidade Federal do Paraná, Fundação O Boticário de Proteção à Natureza, Curitiba, Paraná, Brasil.

Kaufmann, J.H. 1962. Ecology and social behavior of the coati, Nasua narica, on Barro Colorado Island, Panama. Univ. Calif. Publ. Zool. 60: 95-222.

Klink, C.A. \& R.B. Machado. 2005. A conservação do Cerrado brasileiro. Megadiversidade 1: 147-155.

Lanning, D.V. 1976. Density and movements of the coati in Arizona. J. Mammal. 57: 609-611.

Lopes, A.L.B. \& J.E. Mantovani. 2005. Determinação da área de vida e do uso de hábitats pela jaguatirica (Felis pardalis) na região nordeste do Estado de São Paulo. Goiânia, Goiás, Brazil.

Marinho-Filho, J., F.H.G. Rodrigues, M.M. Guimarães \& M.L. Reis. 1998. Os mamíferos da Estação Ecológica de Águas Emendadas, Planaltina, DF, p. 34-63. In J. Marinho-Filho, F.H.G. Rodrigues \& M.M. Guimarães (eds.). Vertebrados da Estação Ecológica de Águas Emendadas: história natural e ecologia em um fragmento de cerrado do Brasil central. Universidade de Brasília, Brasília, Distrito Federal, Brasil.

Minitab 15.0. 2006. Statistical software. State College, 2006. 1 CD-ROM.

Minta, S.C. 1992. Tests of spatial and temporal interaction among animals. Ecol. Appl. 2: 178-188.

Mohr, C.O. 1947. Table of equivalent populations of North American small mammals. Am. Midl. Nat. 37: 223 449.

Nakano-Oliveira, E. \& E.L.A. Monteiro-Filho. 2002. Área de vida e ocupação de hábitat por Cerdocyon thous (Linnaeus, 1766) e Nasua nasua (Linnaeus, 1766) (Mammalia: Carnívora) através de rádio-telemetria. Itajaí, Santa Catarina, Brazil.
Nowak, R.M. 1999. Walker's mammals of the world. John Hopkins University, Maryland, USA.

Ratnayeke, S., A. Bixler \& J.L. Gittleman. 1994. Home range movements of solitary, reproductive female coatis, (Nasua narica) in South-Eastern Arizona. J. Zool. (Lond.) 233: 322-326.

Redford, K.H. \& A.M. Stearman. 1993. Notas sobre la biologia de tres procyonidos simpatricos Bolivianos (Mammalia, Procyonidae). Ecol. Boliv. 21: 35-44.

Resende, B.D., M. Mannu, P. Izar \& E.B. Ottoni. 2004. Interaction between capuchins and coatis: nonagonistic behaviors and lack of predation. Int. J. Primatol. 25: 1213-1224.

Ribeiro R. \& J. Marinho-Filho. 2005. Estrutura da comunidade de pequenos mamíferos (Mammalia Rodentia) da Estação Ecológica de Águas Emendadas, Planaltina, Distrito Federal Brasil. Rev. Bras. Zool. 22: 898-907.

Romero, T. \& F. Aureli. 2007. Spatial association and social behaviour in zoo-living female ring-tailed coatis (Nasua nasua). Behaviour 144: 179-193.

Romero, T. \& F Aureli. 2008. Reciprocity of Support in Coatis (Nasua nasua). J. Comp. Psychol. 122: 19-25.

Schaller, G.B. 1983. Mammals and their biomass on a Brazilian ranch. Arq. Zool. 31: 1-36.

Swihart, R.K. \& N.A. Slade. 1985. Influence on sampling intervals on estimates of home range size. J. Wild. Manag. 49: 1019-1025.

Trovati, R.G., B.A. Brito \& M.S. Munerato. 2006. Captura e contenção físico-química de Nasua nasua em vida livre. São Pedro, São Paulo, Brazil.

Valenzuela, D. \& G. Ceballos. 2000. Habitat selection, home range, and activity of the white-nosed coati (Nasua narica) in a Mexican tropical dry forest. J. Mammal. 81: 810-819.

Valenzuela, D. \& D.W. Macdonald. 2002. Home-range use by white-nosed (Nasua narica): limited water and a test of the resource dispersion hypothesis. J. Zool. (Lond.) 258: 247-256

White, G.C. \& R.A. Garrott. 1990. Analysis of wildlife radio-tracking data. Academic San Diego, California, USA.

Yanosky, A.A. \& C. Mercolli. 1992. Preferencias de hábitat y actividad del coatí común (Nasua nasua) en la Reserva Ecológica el Bagual (Argentina). Misc. Zool. 16: $179-182$. 